Rhizochaete, a New Genus of Phanerochaetoid Fungi

Author(s): Alina Greslebin, Karen K. Nakasone and Mario Rajchenberg

Source: Mycologia, Vol. 96, No. 2 (Mar. - Apr., 2004), pp. 260-271

Published by: Mycological Society of America

Stable URL: http://www.jstor.org/stable/3762062

Accessed: 22-05-2016 06:07 UTC

\title{
REFERENCES
}

Linked references are available on JSTOR for this article:

http://www.jstor.org/stable/3762062? seq=1\&cid=pdf-reference\#references_tab_contents You may need to $\log$ in to JSTOR to access the linked references.

Your use of the JSTOR archive indicates your acceptance of the Terms \& Conditions of Use, available at

http://about.jstor.org/terms

JSTOR is a not-for-profit service that helps scholars, researchers, and students discover, use, and build upon a wide range of content in a trusted digital archive. We use information technology and tools to increase productivity and facilitate new forms of scholarship. For more information about JSTOR, please contact support@jstor.org.

Mycological Society of America is collaborating with JSTOR to digitize, preserve and extend access to Mycologia 


\section{Rhizochaete, a new genus of phanerochaetoid fungi}

\author{
Alina Greslebin ${ }^{1}$ \\ Centro de Investigación y Extensión Forestal Andino \\ Patagónico (CIEFAP), C.C. 14, 9200 Esquel, \\ Chubut, Argentina
}

Karen K. Nakasone ${ }^{2}$

Center for Forest Mycology Research, Forest Products Laboratory, 1 Gifford Pinchot Drive, Madison, Wisconsin 53726-2398

Mario Rajchenberg

Centro de Investigación y Extensión Forestal Andino Patagónico (CIEFAP), C.C. 14, 9200 Esquel, Chubut, Argentina

Abstract: A new basidiomycete genus, Rhizochaete (Phanerochaetaceae, Polyporales), is described. Rhizochaete is characterized by a smooth to tuberculate, pellicular hymenophore and hyphal cords that turn red or violet in potassium hydroxide, monomitic hyphal system of simple or nodose septate hyphae, cystidia, and small, cylindrical to subglobose basidiospores. It morphologically is most similar to Phanerochaete. Analyses of nuclear ribosomal and internaltranscribed spacer region sequence data support a close relationship between Rhizochaete and Phanerochaete. The new taxon $R$. brunnea, from southern Argentina, is described and illustrated. In addition, the new combinations $R$. americana, $R$. borneensis, $R$. filamentosa, $R$. fouquieriae and $R$. radicata are proposed. A key to the species of Rhizochaete is provided.

Key words: Basidiomycetes, Ceraceomyces americanus, Ceraceomyces fouquieriae, internal transcribed spacer region, Phanerochaetaceae, Phanerochaete borneensis, Phanerochaete filamentosa, Phanerochaete radicata, Polyporales, Rhizochaete brunnea, ribosomal DNA, taxonomy

\section{INTRODUCTION}

During a survey of Corticiaceae sensu lato growing on Nothofagus pumilio (Poepp. \& Endl.) Krass. (Greslebin and Rajchenberg 1997a, b, 1998, Greslebin 2001) in the southern forests of Argentina (Cabrera

\footnotetext{
Accepted for publication August 27, 3003.

${ }^{1}$ E-mail: alina@ciefap.cyt.edu.ar

${ }^{2}$ Corresponding author. E-mail: knakasone@fs.fed.us
}

and Willink 1973), an undescribed taxon whose hymenial surface turned violet with drops of $2-5 \%$ $\mathrm{KOH}$ was found. The generic placement of this taxon could not be determined readily from its morphological features because it possessed characters assignable to several genera. The basidiocarp and the hyphal system had a phanerochaetoid appearance, but the hyphae were clamped regularly. In addition, the tubular cystidia with thickened walls were similar to those developed in some species of Crustoderma but differed in being encrusted with crystals and granular material. The taxon was associated with white rot, but the test for extracellular oxidases resulted in a negative or a very weakly positive reaction. The affiliation of this taxon to Phanerochaete P. Karst., Phlebia Fr., Hyphoderma Wallr., Crustoderma Parmasto and Ceraceomyces Jülich was evaluated, but in all cases the new species did not conform to important features of these genera. Several species in the above-mentioned genera that had the hymenial surfaces turning red-violet with $\mathrm{KOH}$ solution showed similarities in hyphal morphology, type of encrustation and cystidia. Because morphological features were insufficient to establish a proper generic disposition, the large and small subunits of the nuclear ribosomal DNA and internal-transcribed spacer (ITS) region were sequenced and analyzed. The analyses showed a close relationship between the Argentinean taxon and Ceraceomyces americanus Nakasone, C.R. Bergman \& Burds., Ceraceomyces fouquieriae (Nakasone \& Gilb.) Nakasone, C.R. Bergman \& Burds., Phanerochaete filamentosa (Berk. \& M.A. Curtis) Burds. and Phanerochaete radicata (Henn.) Nakasone, C.R. Bergman \& Burds. In this paper we describe the new genus Rhizochaete to accommodate these taxa, based on morphological and molecular studies.

\section{MATERIALS AND METHODS}

Morphological and cultural studies.-Freehand sections of fresh and dried basidiocarps were examined microscopically, mounted in $2-5 \%$ potassium hydroxide $(\mathrm{KOH})$ and $1 \%$ aqueous phloxine, Melzer's reagent (reactions amyloid, dextrinoid or none [=IKI-]; Kirk et al 2001), $0.1 \%$ cotton blue in lactophenol and $1 \%$ aqueous cresyl-blue (reaction metachromatic when walls turn purple). Color descriptions were taken from Munsell (1954) and herbarium designations from Holmgren et al (1990). Cultures were obtained 
from context tissue of fresh basidiocarps or isolated from the associated wood rot and are kept at the culture collection at CIEFAP. Cultural features were studied and described according to Nobles (1965). The species code describing the cultures follows the system of Nobles (1965), with several modifications summarized by Nakasone (1990). Line drawings of microscopic features were made with a drawing tube on the microscope. Unless otherwise indicated, all specimens are at CIEFAP.

Phylogenetic analyses.-Taxa used in the phylogenetic analyses are listed in TABLE I. Three datasets, representing three different gene regions of the nuclear ribosomal gene, were analyzed. Based on previous phylogenetic studies of Homobasidiomycetes using the nuclear small-subunit ribosomal RNA gene (SSU rRNA) (Hibbett and Donoghue 2001, Lim 2001), 28 taxa were included in the first dataset, and Gloeophyllum sepiarium (Wulf. : Fr.) P. Karst. was chosen as outgroup taxon. The nuclear large-subunit ribosomal RNA (LSU rRNA) gene region includes 36 taxa of which 19 also were represented in the SSU rRNA dataset. Results from the SSU rRNA analysis and Parmasto's and Hallenberg's (2000) study of the phylogenetic relationships of phlebioid fungi based on the LSU rRNA were used to determine the taxa included in the LSU rRNA dataset. Gloeophyllum sepiarium was designated outgroup taxon in the LSU rRNA dataset as well. The third dataset consists of sequences of the internal transcribed spacer region, including the 5.8S rRNA gene (ITS). Forty taxa were included in the ITS dataset. The taxa in this dataset were based on previous studies (Boidin et al 1998; de Koker et al 2003) and included a number of Phanerochaete species. Representative strains of five taxa of Rhizochaete were included in all three datasets.

Cultures and voucher specimens of strains sequenced in this study are deposited at CFMR (TABLE I). Cultures were grown in $50 \mathrm{ml}$ of sterile $2 \%$ malt extract supplemented with $1 \%$ glucose and $0.1 \%$ yeast extract at $25 \mathrm{C}$ for $1 \mathrm{wk}$. The cultures were harvested by filtration onto Miracloth (Chicopee Mills Inc., La Jolla, California), lyophilized and stored at $-20 \mathrm{C}$. Total DNA was extracted following the protocol outline in Cenis (1992), with minor modifications, and further purified with a Geneclean kit (Qbiogene, Carlsbad, California). The ITS region was amplified with primers ITS5 and ITS4, the SSU RNA gene with primers NS1 and NS8, and the $5^{\prime}$ end of the LSU RNA gene with primers LR0R and LR7 (White et al 1990) using a Taq PCR Core Kit (Qiagen, Hilden, Germany) in a PTC 200 DNA Engine thermal cycler (MJ Research, Watertown, Massachusetts). Primers were prepared by Operon Technologies Inc. (Alameda, California). Cycling parameters were: 1 cycle at $93 \mathrm{C}$ for $2 \mathrm{~min}$, followed by 35 cycles at $53 \mathrm{C}$ for $2 \mathrm{~min}, 72 \mathrm{C}$ for $2 \mathrm{~min}$, and $93 \mathrm{C}$ for $1 \mathrm{~min}$. Amplified DNA products were cleaned with a QIAquick PCR Purification Kit (Qiagen, Hilden, Germany) then sequenced with an ABI Prism BigDye Terminator Cycle Sequencing Ready Reaction Kit (PE Biosystems, Foster City, California), following the manufacturer's protocol. Primers used for sequencing were ITS1, ITS3 and ITS2 or ITS6 for the ITS region, NS1, NS2, NS3, NS5, NS7, NS6, NS8 and sometimes SR4 for the SSU rRNA gene, and LR0R, LR3R, LR17R, LR3, LR5 and LR7 for the LSU
rRNA gene, (http://www.biology.duke.edu/fungi/mycolab/ primers.htm). Sequences were obtained from an ABI Prism 377-18 DNA Sequencer (PE Biosystems, Foster City, California). This overlapping sequencing strategy resulted in the DNA regions being sequenced in both directions, except in a few areas. Sequences obtained from this study were submitted to GenBank (AY219389-AY219404).

Sequences obtained from this study were aligned manually in PAUP* 4.0b10 (Swofford 2002) and McClade (Maddison and Maddison 1992) with those obtained from GenBank (TABLE I). The SSU rRNA, LSU rRNA and ITS regions were analyzed separately. The aligned sequences are available from TreeBASE (S972). In each region, ambiguous sites were excluded before analyses. Phylogenetic analyses of the sequence data were performed with maximumparsimony (MP) and maximum-likelihood (ML) methods, as implemented in PAUP, and with Bayesian inference, using MrBayes version 2.01 (Hulsenbeck and Ronquist 2000). For MP analyses, an initial heuristic search of 100 random taxon addition replicate searches was conducted with TBR branch-swapping, MAXTREES set to autoincrease, without constraints, unordered and equally weighted nucleotides, and retention of two shortest trees. The shortest trees were used as starting trees in a second heuristic search, with TBR branch swapping and MAXTREES set to 5000 to find the most-parsimonious trees. Bootstrap support for clades (Felsenstein 1985) was estimated from 1000 replicate heuristic searches with simple taxon addition sequence, retention of one tree per replicate, TBR branch swapping, and MAXTREES set to 5000. Consistency indices (CI, Kluge and Farris 1969) and retention indices (RI, Farris 1989) exclude uninformative characters. Decay indices (DI, Bremer 1988) were determined with AUTODECAY 4.0 (Eriksson 1998). The program MODELTEST 3.06 (Posada and Crandall 1998) performed nested likelihood ratio tests to determine the best model of sequence evolution for the three datasets. The values obtained from MODELTEST then were used in ML and Bayesian analysis. ML heuristic searches were performed in PAUP with TBR branch swapping. Bayesian analysis was implemented in MrBayes with four Markov chain Monte Carlo chains with no molecular clock enforced. One million or 1500000 generations were performed, with every 100 trees sampled. The first 1000 or 1500 trees were excluded from construction of the consensus tree. Bayesian analyses were performed three times to confirm the consistency of the consensus tree and posterior clade probabilities.

\section{RESULTS}

Rhizochaete Greslebin, Nakasone \& Rajchenb., gen. nov.

Basidioma resupinatum, effusum, pelliculare vel membranaceum. Hymenophorum leve vel leviter tuberculatum, in solutionem $\mathrm{KOH}$ violaceum; rhizomorphis praesentes et perabundans. Systema hyphale monomiticum; hyphae fibulatae vel afibulatae, tenuitunicatae vel crassitunicatae, incrustatae, ochraceis materiis in $\mathrm{KOH}$ dissolventibus. Cystidia typice praesentes. Basidia anguste clavata, tetrasporis. Sporis 
TABLE I. Taxa, strain numbers, and GenBank accession numbers

\begin{tabular}{|c|c|c|c|}
\hline Taxa, strain number & SSU & LSU (strain no. ${ }^{a}$ ) & ITS (strain no. ${ }^{\mathrm{a}}$ ) \\
\hline Abortiporus biennis, KEW 210 & AF334899 & AF287842 & - \\
\hline Albatrellus syringae, CBS 728.85 & AF026632 & AF393045 & - \\
\hline Antrodia carbonica, DAOM 197828 & - & AF287844 & - \\
\hline Antrodia xantha, $\mathrm{K}(\mathrm{M}) 31145$ & - & - & AJ006681 \\
\hline Bjerkandera adusta, DAOM 215869 & AF334904 & AF287848 & AJ006672 (K(M)31061) \\
\hline Bjerkandera fumosa, K(M)32669 & - & - & AJ006673 \\
\hline Byssomerulius albostramineus, FP $100373^{\mathrm{b}}$ & AY219404 & - & - \\
\hline Ceraceomyces eludens, JS 20378 & - & AF090881 & - \\
\hline Ceraceomyces microsporus, JS 22310 & - & AF090876 & - \\
\hline Ceraceomyces serpens, KHL 8478 & - & AF090882 & - \\
\hline Ceriporia purpurea, DAOM 213168 & AF026594 & AF287852 & - \\
\hline Ceriporiopsis gilvescens, JLL $3522^{\mathrm{b}}$ & AY219403 & - & - \\
\hline Ceriporiopsis subvermispora, FP 90031 & AF334906 & AF287853 & - \\
\hline Columnocystis abietina, HНB 12622 & AF082848 & - & - \\
\hline Diplomitoporus lindbladii, $\mathrm{K}(\mathrm{M}) 44271$ & - & - & AJ006682 \\
\hline Fomitopsis pinicola, DAOM 189134 & - & AF287858 & - \\
\hline Gloeophyllum sepiarium, DAOM 137861 & AF026608 & AF393059 & - \\
\hline Gloeoporus taxicola (1), KEW 213 & AF334913 & AF287861 & - \\
\hline Gloeoporus taxicola (2), UL9508151 & AF082682 & - & - \\
\hline Irpex lacteus, IFO 5367 & AF082683 & - & - \\
\hline Leptoporus mollis, K(M) 39893 & - & - & AJ006669 \\
\hline Lopharia spadicea, CBS 474.48 & AF082853 & - & - \\
\hline Meripilus giganteus, DHS 93-193 & AF026568 & AF287874 & - \\
\hline Oxyporus latemarginatus, ATCC 9408 & AF082670 & - & - \\
\hline Panus rudis, DHS 92-139 & - & AF287878 & - \\
\hline Phanerochaete allantospora, KKN 111 & - & - & AY219357 \\
\hline Phanerochaete arizonica, RLG 10816 & - & - & AY219350 \\
\hline Phanerochaete australis, FP 102818 & - & - & AY219373 \\
\hline Phanerochaete avellanea, FP 104126 & - & - & AY219355 \\
\hline Phanerochaete burtii, FP 104384 & - & - & AY219352 \\
\hline Phanerochaete carnosa, HНB 10118 & - & - & AY219354 \\
\hline Phanerochaete chrysorhiza, T484 & - & AF139967 & AY219359 (FP102002) \\
\hline Phanerochaete chrysosporium, FPL 5175 & AF026593 & AF139966 (BKMF1767) & AY219344 (BKMF1767) \\
\hline Phanerochaete crassa, FP 102496 & - & - & AY219341 \\
\hline Phanerochaete ericina, FP 101978 & - & - & AY219345 \\
\hline Phanerochaete hiulca, FP 100589 & - & - & AY219342 \\
\hline Phanerochaete laevis (1), FP 101481 & - & - & AY219347 \\
\hline Phanerochaete laevis (2), FP 101018 & - & - & AY219348 \\
\hline Phanerochaete magnoliae, ННВ 9829 & - & - & AY219343 \\
\hline Phanerochaete omnivorum, НHB 5969 & - & - & AY219360 \\
\hline Phanerochaete rimosa, FP 102099 & - & - & AY219349 \\
\hline Phanerochaete sanguinea, F025062a & - & AJ406533 & AY219353 (FP100391) \\
\hline Phanerochaete sordida (1), НHB 7827 & - & - & AY219377 \\
\hline Phanerochaete sordida (2), ННВ 11458 & - & - & AY219378 \\
\hline Phanerochaete sordida (3), ННВ 9871 & - & - & AY219385 \\
\hline Phanerochaete sordida (4), GEL 4160 & - & AJ406532 & - \\
\hline Phanerochaete subceracea, FP 105974 & - & - & AY219346 \\
\hline Phanerochaete tuberculata, FP 102168 & - & - & AY219356 \\
\hline Phanerochaete velutina, FP 102157 & - & - & AY219351 \\
\hline Phlebia albida, GB 1833 & - & - & AY219368 \\
\hline Phlebia albomellea, FP 101843 & - & - & AY219369 \\
\hline Phlebia centrifuga, FCUG 2396 & - & AF141618 & - \\
\hline Phlebia chrysocreas, FP 102161 & - & - & AY219367 \\
\hline Phlebia concentrica, OSC 41587 & - & - & AY219364 \\
\hline Phlebia deflectens, FCUG 1568 & - & AF141619 & - \\
\hline
\end{tabular}


TABLE I. Continued

\begin{tabular}{|c|c|c|c|}
\hline Taxa, strain number & SSU & LSU (strain no. ${ }^{a}$ ) & ITS (strain no. ${ }^{\mathrm{a}}$ ) \\
\hline Phlebia lilascens (1), FCUG 1801 & - & AF141621 & - \\
\hline Phlebia lilascens (2), FCUG 2005 & - & AF141622 & - \\
\hline Phlebia nitidula, FCUG 2028 & - & AF141625 & - \\
\hline Phlebia radiata, FPL 6140 & AF026606 & AJ406541 (GEL 5258) & AY219366 (JLL 15608) \\
\hline Phlebia rufa, FCUG 2397 & - & AF141628 & - \\
\hline Phlebia subserialis, FCUG 1434 & - & AF141631 & AY219365 (GB240) \\
\hline Phlebia termellosa, JHG $344^{\mathrm{b}}$ & AY219402 & AF141632 (FCUG 1813) & - \\
\hline Phlebiopsis gigantea, НHB 5153 & AF219394 & AF141634 (FCUG 1417) & AF087488 (C-P160) \\
\hline Pulcherricium caeruleum, FPL 7658 & AF334933 & AF393073 & - \\
\hline Rhizochaete americana, HHB $2004^{\mathrm{b}}$ & AY219396 & AY219391 & AY219391 \\
\hline Rhizochaete brunnea, MR 229b & AY219395 & AY219389 & AY219389 \\
\hline Rhizochaete filamentosa, FP $105240^{\mathrm{b}}$ & AY219398 & AY219393 & AY219393 \\
\hline Rhizochaete fouquieriae, $\mathrm{KKN} 121^{\mathrm{b}}$ & AY219397 & AY219390 & AY219390 \\
\hline Rhizochaete radicata, $\mathrm{HHB} 1909^{\mathrm{b}}$ & AY219399 & AY219392 & AY219392 \\
\hline Scopuloides hydnoides, GEL 3859 & - & AJ406573 & - \\
\hline Tyromyces chioneus, KEW 141 & AF334938 & AF393080 & - \\
\hline Tyromyces fumidiceps, FP $105742^{\mathrm{b}}$ & AY219400 & - & - \\
\hline Tyromyces subgiganteus, RLG $6893^{\mathrm{b}}$ & AY219401 & - & - \\
\hline
\end{tabular}

${ }^{a}$ Strain number, if different from that in the first column, is given in parentheses.

${ }^{\mathrm{b}}$ Voucher specimens and cultures are available from CFMR.

brevis cylindraceis, ellipsoideis vel subglogosis, tenuitunicatis, levibus, hyalinis, inamyloideis.

Typus: Rhizochaete brunnea Greslebin, Nakasone \& Rajchenb. sp. nov.

Etymology. Rhizo (Gr. Rhiza $=$ root) referring to the rhizomorphs + chaete $($ Gr. Chaite $=$ hair, setae, spine, bristle) referring to the presence of protruding cystidia.

Basidiocarp pellicular to membranaceous, subceraceous when fresh, coriaceous but friable to firm papyraceous upon drying; readily detachable from substrate and/or subiculum. Hymenial surface continuous, smooth to slightly tuberculate, velutinous, yellowish, orange or brownish colored, turning red to violet with drops of $\mathrm{KOH}$ solution. Context packedhypochnoid to densely wooly. Margin distinct, fimbriate to fibrillose; hyphal cords usually abundant, turning red to violet in $\mathrm{KOH}$.

Hyphal system monomitic; generative hyphae with variable septation (some species simple septate, some species mostly simple septate but a few septa with clamps, and other species regularly clamped), thin to thick-walled, encrusted with dark yellow to yellowish brown, resinous-like granules that dissolve in $\mathrm{KOH}$ turning the solution pale violet; some hyphae also encrusted with hyaline crystals that do not dissolve in $\mathrm{KOH}$. Crystalline encrustation usually restricted to subicular hyphae, and crystals aggregated in clusters or rosette-like structures larger and coarser than the colored granules. Subhymenium well developed, composed of tightly packed hyphae. Subiculum an open and loose textura intricata; a basal textura porrecta stratum usually present next to the substrate. Hyphal system and hymenial elements metachromatic. Cystidia present in all but one species, cylindrical to subfusiform, thin to thick-walled, always encrusted with dark yellow to yellowish-brown resinous-like granules that dissolve in $\mathrm{KOH}$, hyaline crystals usually present. Basidia clavate to subcylindrical and sinuous, thinwalled or thickening towards the base. Basidiospores small, up to $6.5(-7) \mu \mathrm{m}$ long, short cylindrical to ellipsoid, widely ellipsoid to subglobose in one species, thin-walled, sometimes appearing slightly thickened, smooth, inamyloid. Associated rot white, but extracellular oxidase test of cultures may produce a weak or negative reaction.

Comments. This genus is characterized by the combination of detachable, subpellicular to membranaceous basidiocarps, hymenial surface and hyphal cords that turn red or violet in $\mathrm{KOH}$, hyphae and cystidia with two types of encrustation (dark yellow to yellowish-brown granules and hyaline crystals), and small, cylindrical to subglobose basidiospores with thin to slightly thickened walls. The color change of the hymenial surface and hyphal cords is produced by the dark yellow to yellowish-brown granules that coat the hyphae as they dissolve and turn violet in $\mathrm{KOH}$. It is an acid-base reaction as the application of an acid solution recovers the original hymenial color.

Rhizochaete easily is distinguished from morphologically similar corticioid genera. For example, Hyphoderma has cystidia that are similar to those in Rhizo- 
TABLE II. Comparison of some distinguishing basidiocarp features of Rhizochaete species and morphologically similar taxa

\begin{tabular}{|c|c|c|c|c|}
\hline Taxa & $\begin{array}{l}\text { Hymenium reaction } \\
\text { to } 2 \% \mathrm{KOH}\end{array}$ & $\begin{array}{c}\text { Hyphal cord reaction } \\
\text { to } 2 \% \mathrm{KOH}\end{array}$ & $\begin{array}{c}\text { Granules } \\
\text { dissolving } \\
\text { in } 2 \% \mathrm{KOH}\end{array}$ & $\begin{array}{l}\text { Multiple } \\
\text { clamps }\end{array}$ \\
\hline Ceraceomyces cerebrosus & none & none & yes & absent \\
\hline Ceraceomyces sulphurinus & none & none & yes & absent \\
\hline Phanerochaete burtii & none & red & no & present \\
\hline Phanerochaete carnosa & green/black & none & yes & present \\
\hline Phanerochaete crassa & none & $\mathrm{NA}^{\mathrm{b}}$ & $\mathrm{NA}^{\mathrm{b}}$ & absent \\
\hline Phanerochaete flava & none & none & yes & absent \\
\hline Phanerochaete hiulca & red & $\mathrm{NA}^{\mathrm{b}}$ & $\mathrm{NA}^{\mathrm{b}}$ & absent \\
\hline Phanerochaete laevis & $(\text { red })^{\mathrm{a}}$ & $\mathrm{NA}^{\mathrm{b}}$ & yes & present \\
\hline Phanerochaete salmoneolutea & red & none & yes & present \\
\hline Phanerochaete sanguinea & olive-green & olive-green & $\mathrm{NA}^{\mathrm{b}}$ & present \\
\hline Phanerochaete subceracea & reddish brown & none & $\mathrm{NA}^{\mathrm{b}}$ & present \\
\hline Phanerochaete viticola & brown & $\mathrm{NA}^{\mathrm{b}}$ & yes & absent \\
\hline Phlebiopsis gigantea & none & $N^{b}$ & $\mathrm{NA}^{\mathrm{b}}$ & absent \\
\hline Phlebiopsis himalayensis & purple & $\mathrm{NA}^{\mathrm{b}}$ & yes & absent \\
\hline Rhizochaete americana & purplish red & purple & yes & absent \\
\hline Rhizochaete borneensis & $\left(\mathrm{red} /\right.$ violet $^{\mathrm{a}}$ & $\mathrm{red} /$ violet & yes & absent \\
\hline Rhizochaete brunnea & violet & red & yes & absent \\
\hline Rhizochaete filamentosa & purple/pink & red & yes & absent \\
\hline Rhizochaete fouquieriae & $\mathrm{red} /$ violet & $(\mathrm{red})^{\mathrm{a}}$ & yes & absent \\
\hline Rhizochaete radicata & purple/red & red & yes & absent \\
\hline
\end{tabular}

a Parentheses indicate that the color change is present in most but not all specimens.

b Not applicable; hyphal cords or encrusting granules not produced.

chaete but its basidiospores are significantly larger. Crustoderma is associated with a brown rot, whereas Rhizochaete is associated with a white rot. Phlebia sensu stricto (Hjortstam 1997) and Phlebiopsis Jülich can be distinguished by their ceraceous to subgelatinous basidiocarps and tightly packed, agglutinated, subicular hyphae.

Rhizochaete is easily distinguished from the closely related genus Phanerochaete by the hyphal septation in the case of regularly clamped species. Simple-septate species of Rhizochaete develop rare single clamps but never multiple clamps that can be found in Phanerochaete species. Furthermore, all species of Rhizochaete develop a red or violet reaction of both the hymenium and hyphal cords to $\mathrm{KOH}$. Although in some species of Phanerochaete, the hymenium turns red in $\mathrm{KOH}$, the hyphal cords do not, e.g., P. laevis, $P$. salmoneolutea and $P$. subceracea. In other species such as $P$. burtii, the hyphal cords but not the hymenium turn red in $\mathrm{KOH}$. The hymenia of $P$. carnosa and $P$. sanguinea produce a dark green or olive green reaction in $\mathrm{KOH}$. A comparison of the distinguishing basidiocarp traits mentioned above for Rhizochaete and morphologically similar taxa in Ceraceomyces, Phanerochaete and Phlebiopsis is presented in TABLE II.

Rhizochaete can be confused with Ceraceomyces, and several species of Rhizochaete were transferred from
Ceraceomyces. Ceraceomyces, as currently defined, is a collection of heterogeneous taxa, thus broad generalizations and comparisons to Rhizochaete are not possible. However, the type species of Ceraceomyces, $C$. tessulatus (Cooke) Jülich, has a pellicular hymenophore, hyphal cords that do not react with $\mathrm{KOH}$, and lacks encrusting granules on the hyphae.

\section{Rhizochaete brunnea Greslebin, Nakasone \& Raj-} chenb., sp. nov. $\quad$ FIGs. 1-4

Basidiocarpum resupinatum, effusum, crassum, membranaceum; hymenophorum leve vel leviter tuberculatum, brunneum, in solutionem $\mathrm{KOH}$ violaceum; rhizomorphis praesentes et perabundans. Systema hypharum monomiticum; hyphae fibulatae, leviter vel crassi tunicatae, metachromatisque, incrustatae; ochraceis materiis in $\mathrm{KOH}$ dissolventibus. Cystidia cylindraceis, (80-)100-250 × 8-15 $\mu \mathrm{m}$, crassitunicatis, metachromatisque, incrustatis. Basidia anguste clavata, $40-55(-60) \times 5-6 \mu \mathrm{m}$, tetrasporis. Sporae ellipsoideae, 5-6.5(-7) $\times$ 3-3.5 $\mu \mathrm{m}$, parietibus levibus, hyalinis, inamyloideis. Holotypus: BAFC 34527.

Basidiocarp resupinate, membranous, thick $(0.3-2$ $\mathrm{mm}$ ) when fresh, with a coriaceous aspect but breaking readily upon drying, detachable from the substrate. Hymenial surface even to slightly tuberculate, velutinous to pilose under a $10 \times$ lens by the protruding cystidia, when fresh dark yellow, brownishyellow or brown $(10 \mathrm{YR} 6 / 8,5 / 6 ; 7 / 5 \mathrm{YR} 5 / 6)$, slight 
GRESLEBIN ET AL: RHIZOCHAETE GEN. NOV.


FIGs. 1-4. Rhizochaete brunnea micromorphology. 1. Vertical section through the basidiocarp. 2. Basidiospores. 3. Cystidium. 4. Basidia. Scale bars: $1=25 \mu \mathrm{m}, 2-4=10 \mu \mathrm{m}$. 
vinaceous when dried, turning violet in $\mathrm{KOH}$ solution (the original color being recovered upon the application of an acid solution), the coloration is due to the encrusted cystidia and its intensity varies according to cystidia abundance. Context up to $1.5 \mathrm{~mm}$ thick, with a compact hypochnoid texture, brownish yellow (10YR 6/8). Margin generally fibrillose, white or yellow, paler than the hymenial surface, with hyphal cords. Hyphal cords dark yellow, 100-1200 $\mu \mathrm{m}$ diam, firm, branched, abundant in the margin, developed under the basidiocarp and throughout the substrate.

Hyphal system monomitic; generative hyphae clamped, thick-walled, metachromatic, heavily encrusted with small, granular, dark melleous to chestnut-colored material that readily dissolves in $\mathrm{KOH}$ solution and turns the solution lilaceous; some hyphae, especially subicular ones, encrusted with polyhedral, hyaline crystals that do not dissolve in KOH. Subhymenial hyphae tightly intertwined and arranged perpendicular to the substrate, a compact textura intricata or intricata-porrecta, 5-6 $\mu \mathrm{m}$ diam, with walls thickened up to $1 \mu \mathrm{m}$. Subiculum a loose and open textura intricata, subicular hyphae up to $10 \mu \mathrm{m}$ diam, with walls up to $2 \mu \mathrm{m}$ thick, sometimes with secondary simple or ampullate septa, clamps sometimes difficult to discern; toward the base of subiculum hyphae arranged more or less parallel to the substrate; a basal stratum next to substrate usually present, a textura porrecta arranged parallel to the substrate. $H y$ phal cords composed of an inner core of parallel, tightly packed hyphae, 4-6 $\mu \mathrm{m}$ diam, clamped, with walls slightly thick to thickened, hyaline, and smooth, and wider hyphae 10-28 $\mu \mathrm{m}$ diam, sparsely septate, with walls thin to thick, containing refringent material that strongly stain with phloxine (appearing gloeopleurous-like) or, if lacking staining material then with walls up to $4 \mu \mathrm{m}$ thick; outer layer composed of closely or loosely intertwined, yellowish hyphae 4-6 $\mu \mathrm{m}$ diam, with walls slightly thick to thick, heavily encrusted with granular, chestnut-colored granules and scattered, hyaline, polyhedral crystals. Cystidia cylindrical, $(80-) 100-250 \times 8-15 \mu \mathrm{m}$, with thickened walls up to $4 \mu \mathrm{m}$ except in the apex, metachromatic, some with adventitious septa, heavily encrusted with both chestnut-colored material and hyaline crystals. Basidia narrowly clavate, $40-55(-60) \times$ 5-6 $\mu \mathrm{m}$, with 4 sterigmata and a basal clamp, thickwalled toward the base, walls metachromatic. Basidiospores ellipsoid, 5-6.5 $(-7) \times 3-3.5 \mu \mathrm{m}$, thin-walled, smooth, IKI-, guttulate.

Habitat. In pure stands of Nothofagus pumilio and mixed forests of $N$. pumilio and N. betuloides (Mirb.) Blume, fruiting on much-decayed logs in humid environments. HOLOTYPE. ARGENTINA. TIERRA
DEL FUEGO: Ushuaia, Estancia el Valdéz, Río Valdez, on rotten trunk of Nothofagus pumilio, 5 Mar 1996, leg. A. Greslebin 278, BAFC 34527 in BAFC.

Specimens examined. ARGENTINA. TIERRA DEL FUEGO: Ushuaia, Estancia el Valdéz, Río Valdéz, on fallen $N$. pumilio, 5 Mar 1996, leg. A. Greslebin 280, Ibid., 23 Mar 1998, leg. ipse 1449, 1450 and 1455; Ibid., 23 Mar 1998, leg. M. Rajchenberg 11455, BAFC 34528. Montaña El Martial, on fallen $\log$ in mixed forest of $N$. pumilio and N. betuloides, 27 Mar 1998, leg. M. Rajchenberg 11572 and 11578; Ibid., 27 Mar 1998, leg. A. Greslebin 1576 and 1577. Lago Escondido, 10 Nov 1998, leg. M. Rajchenberg 11844; Ibid., 26 Apr 1999, leg. A. Greslebin 1957. Parque Nacional Tierra del Fuego, Río Pipo, 7 Nov 1998, leg. M. Rajchenberg 11782,11785 and 11837. Paseo del Turbal y Castorera, 25 Apr 1999, leg. A. Greslebin 1921. Río Negro, Parque Nacional Nahuel Huapi, Puerto Blest, 6 May 1999, leg. M. Rajchenberg 11873 and 11890 .

Remarks. The brown, strongly velutinous hymenophore, the large cystidia, the thick-walled hyphal system and the relatively large basidia, with walls that thicken toward the base, distinguish this species from the others in the genus.

Cultural description.-

FIGS. 5-10

Cultures studied. No. 229, from basidiocarp M. Rajchenberg 11455; No. 230, from associated decayed wood and mycelia of basidiocarp A. Greslebin 1577.

Macroscopic characters. Growth very slow, $6-6.5 \mathrm{~cm}$ radius by $6 \mathrm{wk}$. Margin regular, hyaline, submerged in the agar. Behind the margin a woolly mat is formed, first as isolated punctual flakes that develop into a heterogeneous, felty to woolly, dark yellow to brownish yellow mat, with scattered denser areas, often with incipient hyphal cord formation. Drops of $\mathrm{KOH}$ solution turn the mat lilac or violet, but the color vanishes rapidly. Reverse bleached. Odor slightly sweet, fruity.

Oxidase reactions. GAA: \pm , growth: trace; TAA: \pm , growth: trace.

Microscopic characters. Marginal hyphae clamped, 3-5 $\mu \mathrm{m}$ diam, thin-walled, hyaline, branched, with long hyphal segments. Aerial mat with thin- and thick-walled generative hyphae covered with minute, dark yellow to brownish granules that readily dissolve in $\mathrm{KOH}$ solution. The size of these granules obscures their shape. At wk 6 some hyphae develop gelatinous, rough walls. Hyaline, polyhedral crystals formed on the hyphae and in the agar.

Species code. 1.(2).3.27.31d.31e.32.37.40.47.50.54

Remarks. Cultural features of Rhizochaete brunnea are similar to those of other Rhizochaete species (Nakasone et al 1994), including its negative or weak oxidase reactions on GAA and TAA. However, the slow growth rate of $R$. brunnea is unusual in the genus. 


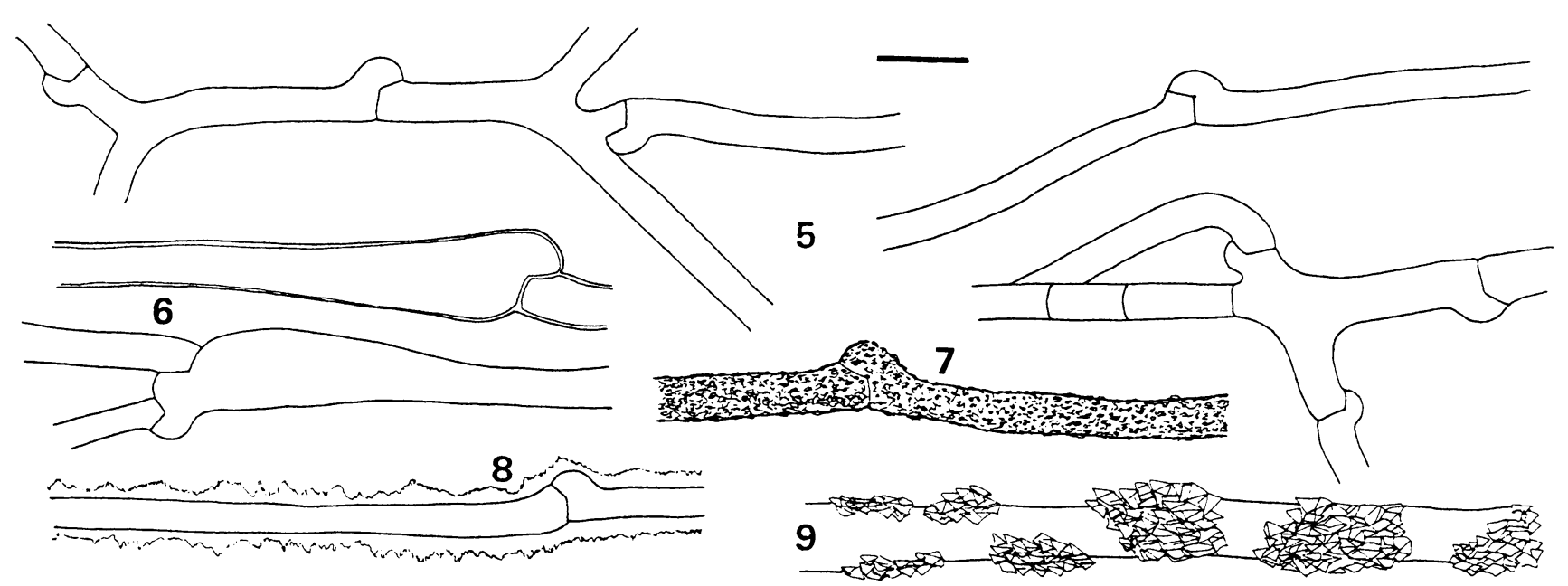

FIGS. 5-9. Rhizochaete brunnea cultural characters. 5. Marginal hyphae. 6. Ampullate septa. 7. Hypha encrusted with granular material. 8. Hyphae with gelatinous, roughened walls. 9. Hyphae encrusted with hyaline crystals. Scale bar $=$ $10 \mu \mathrm{m}$.

Rhizochaete americana (Nakasone, C.R. Bergman \& Burds.) Greslebin, Nakasone \& Rajchenb., comb. nov.

Basionym: Ceraceomyces americanus Nakasone, C.R. Bergman \& Burds., Sydowia 46:56. 1994.

Remarks. Key characters of this species are clamped hyphae, fusiform, thin-walled cystidia, 33$44(-60) \times 5-9(-12) \mu \mathrm{m}$, encrusted only with yellowish brown granules, and short cylindrical to ellipsoid basidiospores, $4-5(-5.5) \times 2-2.5(-3) \mu \mathrm{m}$; reported

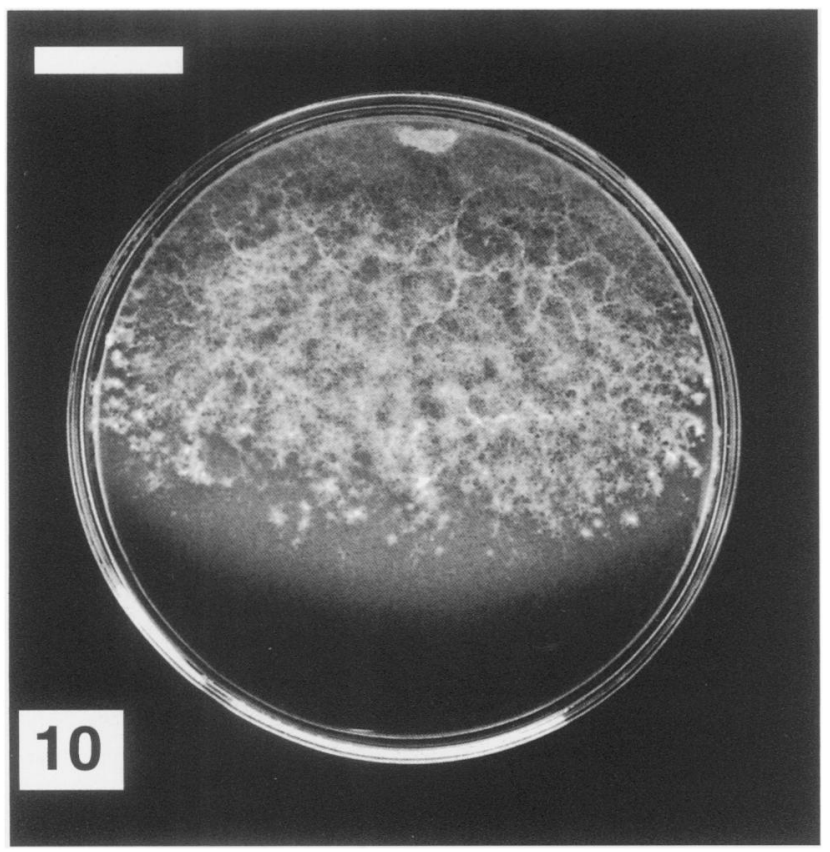

FIG. 10. Rhizochaete brunnea. Macroscopic aspect of culture at $6 \mathrm{wk}$. Scale bar $=20 \mathrm{~mm}$. from eastern North America. For a full description and illustrations, see Nakasone et al (1994).

Rhizochaete borneensis (Jülich) Greslebin, Nakasone \& Rajchenb., comb. nov.

Basionym: Phanerochaete borneensis Jülich, J. Linn. Soc., Bot. 81:43. 1980.

Remarks. Key characters of this species are the bright yellow subiculum, simple septate hyphae with scattered single clamp connections, short, thin- to thick-walled cystidia, $20-33(-50) \times 4.5-9 \mu \mathrm{m}$, encrusted with coarse, hyaline crystals, and broadly ellipsoid to subglobose basidiospores, 4-5 $\times$ 2.8-3.2 $\mu \mathrm{m}$, with thin to slightly thick walls; reported from Borneo and Brunei (Hjortstam et al 1998).

Rhizochaete filamentosa (Berk. \& M.A. Curtis) Greslebin, Nakasone \& Rajchenb., comb. nov.

Basionym: Corticium filamentosum Berk. \& M.A. Curtis in Berk., Grevillea 1(12):178. 1873.

Remarks. Key characters of this species are simple septate hyphae with rare single clamp connections in the subiculum, cylindrical to narrowly obclavate cystidia, mostly thin-walled, with secondary septa, (30-) 40-60 × 5-7 $\mu \mathrm{m}$, usually encrusted with both hyaline crystals and colored granules, and short cylindrical basidiospores, 4-5 $\times 2-2.5 \mu \mathrm{m}$; reported from eastern North America. For a full description and illustrations, see Nakasone et al (1994).

Rhizochaete fouquieriae (Nakasone \& Gilb.) Greslebin, Nakasone \& Rajchenb., comb. nov. 
TABLE III. Summary of likelihood models of evolution and parameters of three gene regions

\begin{tabular}{|c|c|c|c|c|c|c|c|}
\hline \multirow{2}{*}{$\begin{array}{l}\text { Gene } \\
\text { region }\end{array}$} & \multirow[b]{2}{*}{ Model $^{\mathrm{a}}$} & \multirow[b]{2}{*}{ PINV $^{\mathrm{b}}$} & \multirow[b]{2}{*}{$\alpha^{c}$} & \multicolumn{4}{|c|}{ Base frequencies } \\
\hline & & & & A & $\mathrm{C}$ & G & $\mathrm{T}$ \\
\hline SSU & $\mathrm{F} 81+\mathrm{G}$ & 0 & 1.629 & 0.4043 & 0.1639 & 0.1654 & 0.2664 \\
\hline LSU & $\operatorname{TrNef}+\mathrm{I}+\mathrm{G}$ & 0.6114 & 0.6414 & 0.25 & 0.25 & 0.25 & 0.25 \\
\hline ITS & $\mathrm{HKY}+\mathrm{I}+\mathrm{G}$ & 0.3960 & 0.6828 & 0.2693 & 0.2153 & 0.2001 & 0.3153 \\
\hline
\end{tabular}

a F81, Felsenstein (1981); TrNef, Tamura-Nei equal base frequencies; HKY, Hasegawa-Kishino-Yano (Hasegawa et al 1985); I, proportion of invariant sites; G, shape parameter of the gamma distribution.

${ }^{\mathrm{b}}$ Proportion of invariant sites.

c Gamma distribution shape parameter.

Basionym: Hyphoderma fouquieriae Nakasone \& Gilb., Mycologia 70(2):272. 1978.

Remarks. Key characters of this species are clamped hyphae, cylindrical to clavate cystidia, thinto slightly thick-walled, $35-55 \times 5.5-8 \mu \mathrm{m}$, usually encrusted with both hyaline crystals and colored granules, and ellipsoid basidiospores, 5-6 $\times 3-4 \mu \mathrm{m}$; reported from Arizona. For a full description, see Nakasone and Gilbertson (1978).

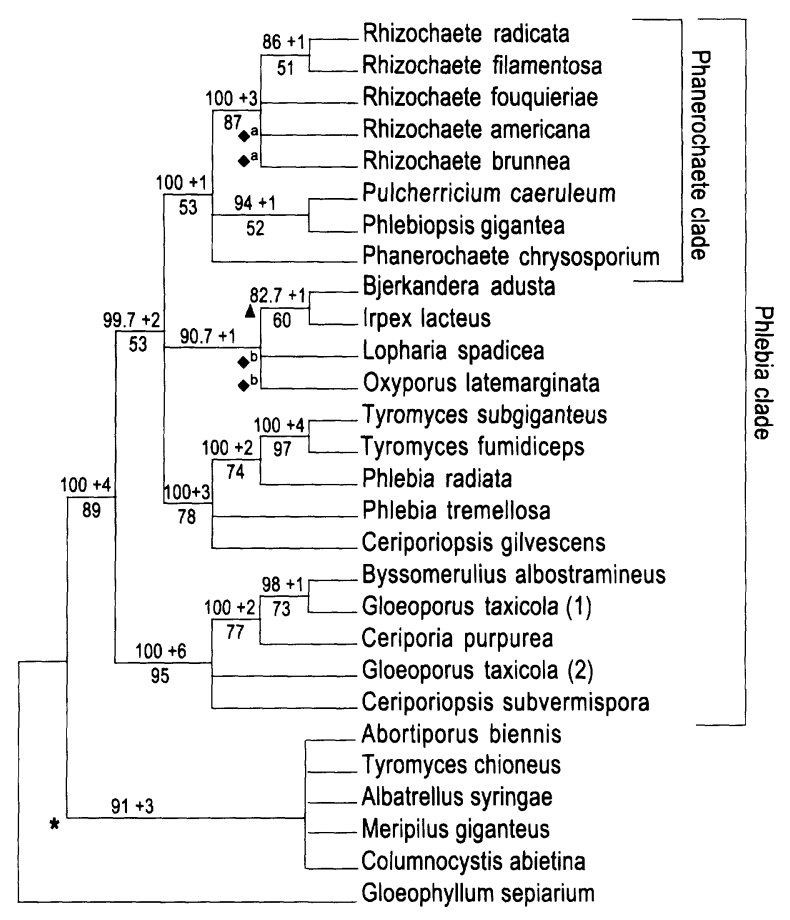

FIG. 11. Strict consensus of 385 most-parsimonious trees (tree length $=209$ steps, $\mathrm{CI}=0.496, \mathrm{RI}=0.712$ ) of the small-subunit ribosomal RNA gene region. Numbers above the branches are average posterior clade probabilities from three Bayesian analyses. Decay indices are indicated above the branches preceded by a + sign. Bootstrap confidence levels are shown below the branches; values $<50 \%$ are not shown. Asterisks $(*)$ and triangles $(\boldsymbol{\Delta})$ indicate nodes that collapse in the Bayesian and maximum-likelihood trees, respectively. Diamonds $(\diamond)$ with the same superscript letter indicate branches that are joined in maximum-likelihood and Bayesian trees.
Rhizochaete radicata (Henn.) Greslebin, Nakasone \& Rajchenb., comb. nov.

Basionym: Corticium radicatum Henn., Pflanzenw. Ost-Afrikas, Lieferung 1, Theil C, p. 54. 1895.

Remarks. Key characters of this species are simple septate hyphae with rare single clamps connections in the subiculum, mostly thick-walled, clavate to fusiform cystidia, (40-)60-100(-115) $\times 5-7 \mu \mathrm{m}$, usually encrusted with both hyaline crystals and colored granules, and short cylindrical to ellipsoid basidiospores, 4-5(-5.5) $\times(2.2-) 2.5-3 \mu \mathrm{m}$; reported worldwide. For a full description, see Nakasone et al (1994).

Sequence alignments.-The SSU rDNA region sequence alignment totaled 1817 base pairs (bp), of which 119 characters $(6.5 \%)$ were excluded because of ambiguity in alignment; 139 remaining characters were variable, of which only $56(3 \%)$ were parsimony informative. In contrast, the ITS region was the shortest at $866 \mathrm{bp}$ and was the most difficult to align. More than half of the ITS characters, 455 bp (53\%), were excluded; 161 characters were variable, and of these 115 (29\%) were parsimony informative. The LSU rDNA region was 932 bp long; 86 (9\%) ambiguous characters were excluded, 222 characters were variable and $155(17 \%)$ characters were parsimony informative. TABLE III lists the likelihood models used in the ML and Bayesian analyses of the three gene regions.

Sequence analyses.-The Rhizochaete taxa always formed a monophyletic clade in MP, ML, and Bayesian analyses of the SSU rDNA dataset. There were $385 \mathrm{MP}$ trees of 209 steps, with $\mathrm{CI}=0.499$ and $\mathrm{RI}=$ 0.712. The strict MP consensus tree shown in FIG. 11 is congruent with, but slightly less resolved than, the ML and Bayesian trees. Rhizochaete is included in the unresolved Phanerochaete clade, nested within the larger Phlebia clade of Hibbett and Donoghue (2001).

Phylogenetic analyses of the LSU rDNA produced trees that generally are congruent with the trees of 


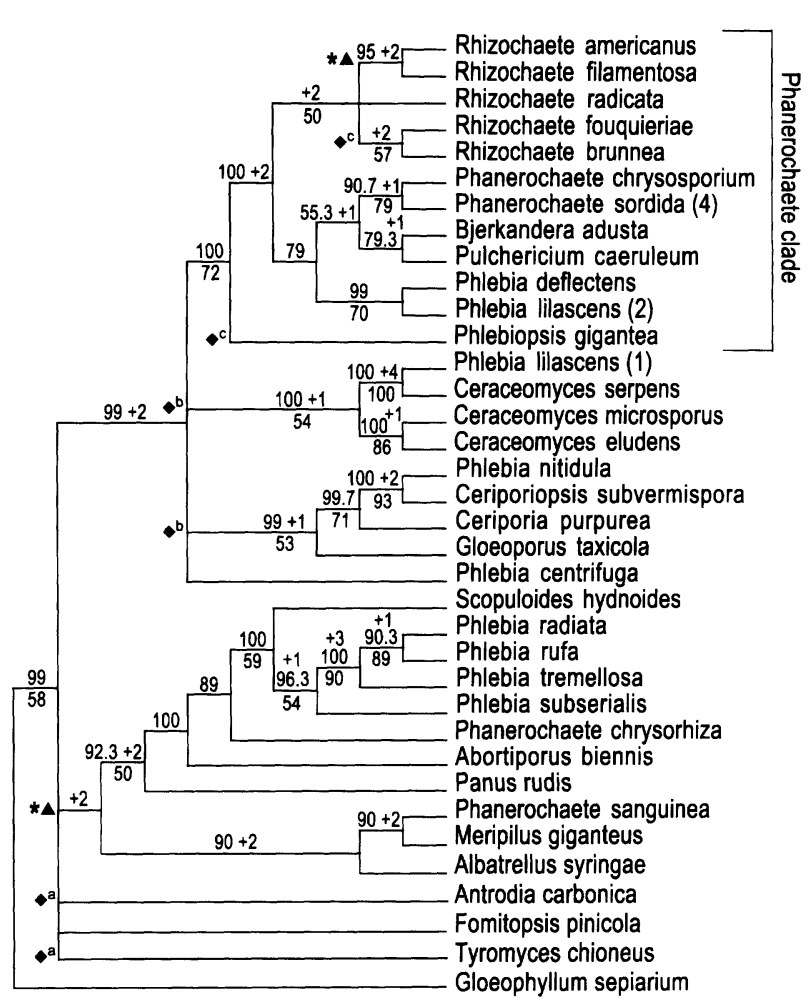

FIG. 12. Strict consensus of 14 most-parsimonious trees (tree length $=739$ steps, $\mathrm{CI}=0.323, \mathrm{RI}=0.519$ ) of the large-subunit ribosomal RNA gene region. Symbols and numbers are described in Fig. 11.

the SSU region, although less than half of the taxa are shared between the two datasets. There were 14 MP trees of 739 steps with $\mathrm{CI}=0.323$ and $\mathrm{RI}=0.519$. The strict MP consensus tree of the LSU region is shown in FIG. 12. In this tree, the Rhizochaete species form a monophyletic clade that is sister to a heterogeneous clade containing Phanerochaete chrysosporium, Phan. sordida, Bjerkandera adusta, Pulcherricium caeruleum, Phlebia deflectens and Phl. lilascens. These two clades and Phlebiopsis constitute the Phanerochaete clade. The ML and Bayesian trees generally are congruent but more resolved than the MP consensus tree. Some branches paired in the ML and Bayesian trees but not in the MP trees are indicated on the figure. Note that in the ML and Bayesian trees Phlebiopsis gigantea is included in a clade with $R$. fouquieriae and $R$. brunnea. This Rhizochaete/P. gigantea clade had an average $98.7 \%$ credibility value by Bayesian analysis but only a 50\% MP bootstrap confidence level. The other Phanerochaete species fall outside the Phanerochaete clade: Phan. sanguinea clusters with Meripilus giganteus and Albatrellus syringae, whereas Phan. chrysorhiza clusters with Phlebia spp. and Scopuloides hydnoides.

The ITS dataset includes a number of Phanerochaete species. There were 2658 most-parsimonious

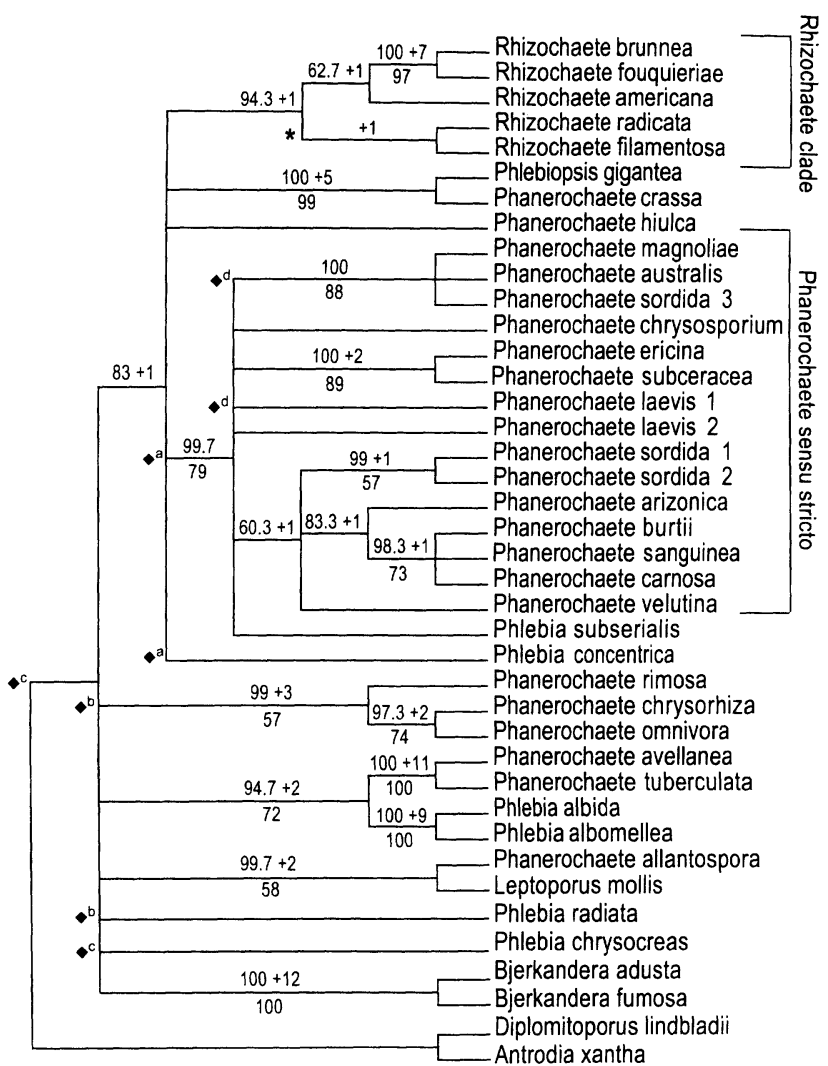

FIG. 13. Strict consensus of 2658 most-parsimonious trees (tree length $=453$ steps, $\mathrm{CI}=0.433, \mathrm{RI}=0.613$ ) from maximum-parsimony analysis of the internal transcribed spacer region. Symbols and numbers are described for FIGS. 11 and 12.

trees of 453 steps long with $\mathrm{CI}=0.433$ and $\mathrm{RI}=$ 0.613. In the strict MP consensus tree in FIG. 13, the Rhizochaete species form a monophyletic clade that is part of a five-way polytomy that includes Phlebiopsis gigantea/Phan. crassa, Phan. hiulca, a large, poorly resolved Phanerochaete sensu stricto clade that includes Phlebia subserialis and Phlebia concentrica. The ML and Bayesian tree topologies are similar but more resolved than the strict MP consensus tree; a few of the joined branches are indicated in the figure. In the ML and Bayesian trees, the Rhizochaete, P. gigantea/Phan. crassa and Phan. hiulca lineages are not included in the Phanerochaete sensu stricto clade that also includes Phl. subserialis and Phl. concentrica.

\section{DISCUSSION}

The most striking and consistent character of the new genus Rhizochaete is the red to violet reaction of the basidiocarp and hyphal cords to $\mathrm{KOH}$ that is related to the dark yellow to yellowish-brown granules that coat the hyphae and cystidia. This feature, though, is present in some species of Phanerochaete, Ceraceomyces, Phlebia and unrelated taxa such as $\mathrm{Hy}$ - 
phodontia australis (Berk.) Hjortstam (Greslebin et al 2000). Other significant characters are the "phanerochaetoid" appearance of the hyphal system, the structure of the subiculum and subhymenium, the hyphal cords, and the shape and size of the basidiospores that are similar to some Phanerochaete species. The sum of these morphological characters indicates a close relationship of Rhizochaete to the genus Phanerochaete, and this relationship also is supported by molecular data.

Rhizochaete consists of species that have a monomitic hyphal system with either regularly nodose septate, regularly simple septate, or simple septate with scattered single clamps. In most genera in the Aphyllophorales, the species have one type of hyphal septation. It is not unusual, however, for one or more species to have simple septate hyphae in a genus of primarily nodose septate species. Examples of these genera include Hyphoderma Wallr., Hyphodontia J. Erikss., Phlebia Fr., Radulodon Ryvarden, Resinicium Parmasto and Veluticeps (Cooke) Pat. A few corticioid genera, namely Botryobasidium Donk and Peniophora Cooke, include a significant number of nodose septate and simple septate species.

Ribosomal DNA analyses support the formation of the new genus Rhizochaete. In general, analyses of the SSU, LSU and ITS-sequence data by MP, ML and Bayesian methods produced trees that support the monophyly of the Rhizochaete species. However, with ML and Bayesian analyses of the LSU, Phlebiopsis gigantea was included also in the Rhizochaete clade. Rhizochaete is closely related to the Phanerochaete sensu stricto clade. Of the taxa included in the datasets, Phlebiopsis gigantea, Phan. crassa and Phan. hiulca, appear to be the most closely related to Rhizochaete. These results are congruent with a phylogenetic study of the genus Phanerochaete that employed the ITS region (de Koker et al 2003).

The Rhizochaete clade is relatively consistent in the analyses of the three datasets, although the positions of other taxa are not. Most of the conflicting results involve taxa in the LSU trees. For example, Bjerkandera adusta is embedded in the Phanerochaete clade in the LSU trees but not in the SSU and ITS trees. Boidin et al (1998) found that three species of Bjerkandera clustered together in a distinct clade basal to the Phanerochaete clade in an analysis of the ITS region. Phlebia subserialis similarly clusters with the Phanerochaete sensu stricto group in the ITS trees, also reported by Boidin et al (1998), but joins other Phlebia species in LSU (Parmasto and Hallenberg 2000) and SSU rDNA sequence analyses (Suhara et al 2002). In another example, Phan. sanguinea clusters with Phan. burtii and Phan. carnosa in the Phanerochaete sensu stricto clade in ITS trees. However, in the
LSU trees, Phan. sanguinea is in a clade with Meripilus giganteus and Albatrellus syringae, basal representative taxa of the polyporoid clade (Hibbett and Donoghue 2001) and far removed from the Phanerochaete clade. Perhaps some of these inconsistencies and other minor ones not mentioned could be resolved with better taxon sampling and the inclusion of protein coding sequences. Sequences from all three DNA regions unfortunately were available only for eight taxa, so a combined sequence analysis was not attempted.

In a study of the mitochondrial SSU rRNA gene, Ko and others (2001) reported that Phan. filamentosa clustered with Antrodia carbonica and Oligoporus fragilis instead of B. adusta and Phan. chrysosporium. This is not consistent with results presented here and might reflect a misidentified specimen or a different mode of evolution of the mitochondrial SSU rRNA gene from that of the nuclear rRNA genes.

In conclusion, Rhizochaete is a polythetic genus that is defined by the combination of basidiocarp macromorphology, including hyphal cords, and its reaction with $\mathrm{KOH}$, hyphal septation, hyphal arrangement, two types of encrustation, cystidia, and basidiospore shape and size. The recognition of this new genus also is supported by molecular data.

\section{KEY OF THE SPECIES OF RHIZOCHAETE}

1. Generative hyphae simple-septate, with scattered sin-

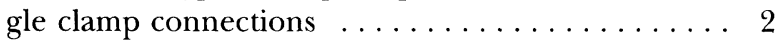

1. Generative hyphae regularly clamped (nodose-septate $\ldots \ldots \ldots \ldots \ldots \ldots \ldots \ldots \ldots \ldots$

2. Cystidia with thin walls, reported from eastern North America . . . . . . . . . . R. filamentosa

2. Cystidia with thickened walls .......... 3

3. Cystidia generally $<50 \mu \mathrm{m}$ long, reported from Borneo and Brunei ............... borneensis

3. Cystidia generally $>50 \mu \mathrm{m}$ long, widely distributed

$\ldots \ldots \ldots \ldots \ldots \ldots \ldots \ldots$ radicata

4. Cystidia thin-walled, encrusted with yellowish brown granules only, reported from eastern North America ............... R. americana

4. Cystidia encrusted with both yellowish brown granules and hyaline crystals ............ 5

5. Cystidia thick-walled, $>80 \mu \mathrm{m}$ long, basidiospores ellipsoid, $5-6.5(-7) \times 3-3.5 \mu \mathrm{m}$, reported from Argentina ..................... brunnea

5. Cystidia thin- to slightly thick-walled, $<80 \mu \mathrm{m}$ long, basidiospores ellipsoid to broadly ellipsoid, 5-6 $\times 3$ $4 \mu \mathrm{m}$, reported from southwestern U.S.A. . . . . . $\ldots \ldots \ldots \ldots \ldots \ldots \ldots \ldots \ldots$ fouquieriae

\section{ACKNOWLEDGMENTS}

We thank Agencia Nacional de Promoción Científica y Técnica, Argentina (PMT-PICT 4062/96 and 4044/98), for supporting AG and MR, researchers for the National Research 
Council of Argentina (CONICET). Dr. N. Hallenberg (Gothenburg, Sweden) provided several herbarium specimens used in this study.

\section{LITERATURE CITED}

Boidin J, Mugnier J, Canales R. 1998. Taxonomie moleculaire des Aphyllophorales. Mycotaxon 66:445-491.

Bremer K. 1988. The limits of amino acid sequence data in angiosperm phylogenetic reconstruction. Evolution 42(4):795-803.

Cabrera AL, Willink A. 1973. Biogeografía de América Latina. Washington, D.C.: Porgrama Regional de Desarrollo Científico y Tecnológico. $122 \mathrm{p}$.

Cenis JL. 1992. Rapid extraction of fungal DNA for PCR amplification. Nuc Acids Res 20(9):2380.

de Koker TH, Nakasone K, Haarhof J, Burdsall Jr HH, Janse BJH. 2003. Phlyogenetic relationships of the genus Phanerochaete inferred from the internal transcribed spacer region. Mycol Res 107(9):1032-1040.

Eriksson T. 1998. AutoDecay. Version 4.0. Department of Botany, Stockholm University, Stockholm: distributed by the author.

Farris JS. 1989. The retention index and homoplasy excess. Syst Zool 38(4):406-407.

Felsenstein J. 1981. Evolutionary trees from DNA sequences: a maximum likelihood approach. J Mol Evol 17: 368-376.

- 1985. Confidence limits on phylogenies: an approach using the bootstrap. Evolution 39(4):783-791.

Greslebin AG. 2001. Sistotremataceae (Corticiaceae, Aphyllophorales) of the Patagonian Andes forests of Argentina. Mycol Res 105(11):1392-1396.

—_ Rajchenberg M. 1997a. Corticioid Aphyllophorales (Basidiomycota) from the Patagonian Andes forests of Argentina. 1. Lachnocladiaceae on Nothofagus pumilio. Mycotaxon 65:197-203.

1997b. Corticioid Aphyllophorales (Basidiomycota) from the Patagonian Andes forests of Argentina. 2. Hyphodontia decorticans sp. nov. Mycotaxon 65: 205-209.

— - 1998. Corticioid Aphyllophorales (Basidiomycotina) from the Patagonian Andes forests of Argentina. 3. The genus Dendrothele. Mycotaxon 67:469-486.

,-- , Bianchinotti MV. 2000. On Hyphodontia australis (Corticiaceae, Basidiomycota). Mycotaxon 74(1):37-43.

Hasegawa M, Kishino H, Yano T. 1985. Dating of the human-ape splitting by a molecular clock of mitochondrial DNA. J Mol Evol 22:160-174.

Hibbett DS, Donoghue MJ. 2001. Analysis of character correlations among wood decay mechanisms, mating systems, and substrate ranges in Homobasidiomycetes. Syst Biol 50(2):215-242.

Hjortstam K. 1997 (1998). Checklist to genera and species of corticioid fungi (Basidiomycotina, Aphyllophorales). Windahlia 23:1-54.

- Roberts PJ, Spooner BM. 1998. Corticioid fungi from Brunei Darussalam. Kew Bull 53(4):805-827.

Holmgren PK, Holmgren NH, Barnett LC. 1990. Index herbariorum. Part I: The herbaria of the world. 8th ed. Reg Veg 120:1-693.

Hulsenbeck JP, Ronquist FR. 2000. MrBayes: a program for the Bayesian inference of phylogeny. Biometrics 17: 754-755.

Kirk PM, Cannon PF, David JC, Stalpers JA. 2001. Ainsworth \& Bisby's Dictionary of the Fungi. Wallingford, United Kingdom: $\mathrm{CAB}$ International. $655 \mathrm{p}$.

Kluge AG, Farris JS. 1969. Quantitative phyletics and the evolution of anurans. Syst Zool 18:1-32.

Ko KS, Jung HS, Ryvarden L. 2001. Phylogenetic relationships of Hapalopilus and related genera inferred from mitochondrial small subunit ribosomal DNA sequences. Mycologia 93(2):270-276.

Lim YW. 2001. Systematic study of corticioid fungi based on molecular sequence analyses [Doctoral dissertation]. Seoul, South Korea: Seoul National University. 228 p.

Maddison WP, Maddison DR. 1992. MacClade version 3. Sunderland, Massachusetts: Sinauer Associates.

Munsell Company. 1954. Munsell soil color charts. Baltimore.

Nakasone KK. 1990. Cultural studies and identification of wood-inhabiting Corticiaceae and selected Hymenomycetes from North America. Mycol Mem 15:1-412.

—_, Bergman CR, Burdsall Jr HH. 1994. Phanerochaete filamentosa-Corticium radicatum species complex in North America. Sydowia 46(1):44-62.

_- Gilbertson RL. 1978. Cultural and other studies of fungi that decay ocotillo in Arizona. Mycologia 70(2): 266-299.

Nobles MK. 1965. Identification of cultures of wood-inhabiting Hymenomycetes. Can J Bot 43:1097-1139.

Parmasto E, Hallenberg N. 2000. A taxonomic study of phlebioid fungi (Basidiomycota). Nord J Bot 20:105118.

Posada D, Crandall KA. 1998. MODELTEST: testing the model of DNA substitution. Bioinformatics 14(9):817818.

Suhara H, Maekawa N, Kubayashi T, Sakai K, Kondo R. 2002. Identification of the basidiomycetous fungus isolated from butt rot of the Japanese cypress. Mycoscience 43:477-481.

Swofford DL. 2002. PAUP*. Phylogenetic Analysis Using Parsimony (*and other methods). Version 4. Sunderland, Massachusetts: Sinauer Associates.

White TJ, Bruns TD, Lee S, Taylor JW. 1990. Amplification and direct sequencing of fungal ribosomal RNA genes for phylogenetics. In: Innis MA, Gelfand DH, Sninsky JJ, White TJ, eds. PCR Protocols: a guide to methods and applications. San Diego, California: Academic Press. p 315-322. 